\title{
NEW MARKETING TOOLS IN THE BLOOD SERVICE TO OPTIMIZE QUALITY MANAGEMENT
}

D0I: 10.36740/WLek202109129

\author{
Vladislav V. Liubchak', Liliia M. Khomenko' , Michael P. Kovalishyn', Viktoriia V. Ilyina', Tetiana V. Babar', \\ Volodymyr V. Sikora', Olha V. Simonova² \\ 'SUMY STATE UNIVERSITY, SUMY, UKRAINE \\ 2PRIVATE CLINIC,ANDROS", KHERSON, UKRAINE
}

\begin{abstract}
The aim: To identify the main fears of donation among young people in the city and ways to eliminate these phobias with the help of modern marketing tools. Materials and methods: It was conducted the questionnaire among Sumy State University students on donation fears. The questionnaire included questions about experience of donation, reason for non donation and age. After that a focus group among students who feared donation was organized. Participants were shown a 360 degree video recorded in the blood center and discussed how to donate blood after watching the video.

Results: The main phobias were fear of becoming infected during the procedure (37.7\%), fear of the procedure itself due to ignorance and misunderstanding of what to expect $(14.0 \%)$, and fear of the needle, blood, and the discomfort possibility during the procedure (10.0\%); $26.7 \%$ indicated that they could not be donors due to poor health, and $11.6 \%$ due to personal laziness. It was developed a 3600 video, which demonstrates the blood donation process, showing the next steps with the selected blood in facilities. Its continues for 20 minutes. This video was shown in the focus group for ten non-donors with some donation fear. $60 \%$ of them reported a change from blood to a positive, which may indicate this tool's effectiveness.

Conclusions: Due a 3600 video some non-donor people can ensure safety, sterility of the process, reduce the fear of donation and further increase the likelihood of becoming regular donors.
\end{abstract}

KEY WORDS: virtual reality, marketing recruitment, fears of donors, blood service management

Wiad Lek. 2021;74(9 p.l):2192-2196

\section{INTRODUCTION}

According to scientific research, there is a catastrophic shortage of blood donors in Ukraine. It is estimated that 33 donations per year per 1,000 inhabitants are the norm for developed countries. Currently, this ratio is 11.28 donations per 1,000 population [1]. Moreover, $70 \%$ of donors in Ukraine donated blood only once in their lives. There is a constant shortage of blood in medical facilities with proper safety. Therefore, it is essential to find out why people do not donate blood and find ways to provide them with modern marketing communication tools.

In recent years, the number of studies on marketing activities in blood service facilities has increased [2-4] as well as number of specific marketing tools [5-8].

Much attention is paid by scientists to the motivation of donors and the factors influencing potential donors' behavior.

Many studies have investigated the factors that deter people from being donors [9-16]. Some authors tried to systematize them [9;14], are offered tools for their elimination $(10 ; 17]$. The subjects of the study were different categories of the population: youth [10], migrants and minorities [10, and the population of individual regions [17-18].

Some researches in the review focus on what is holding back primary donors and what measures can help keep this group going. Bagot identified traditional, behavioral, or social factors [9].

Other authors developed a four-factor structure associated with fears: 1) symptoms of the syncopal system (fainting and dizziness), 2) blood and needles, 3) social assessment, and 4) the results of a health study [14].

Although the risk of fainting and dizziness is low during blood donation, it remains a problem for many donors [15].

Some of restraining factors is post-donation adverse reactions, which occur in $0.08-13 \%$ of donors in different countries, were systemic and can be caused by many factors [12].

Some researchers found that medical fears, including blood fears, play a great role in future attitudes and intentions regarding donation [12].

Other researches analyzed culturally specific factors influencing donor motivation in South Africa. They classified all deterrents into fears, negative attitudes, and lack of knowledge. In addition to the generally accepted factors (fear and lack of awareness), a unique factor for the South African population was found - skepticism, generated by the perception of racial discrimination in blood sampling [18]. 
Some researchers studied the factors influencing blood donation among migrants or minorities in sub-Sahara. He identified the following significant periodic barriers: delays due to insufficient hemoglobin, fear of needles and pain, social exclusion, lack of awareness, negative attitudes toward donation, and problems with the availability of blood center locations. Significant incentives for the studied populations are altruism, free medical examinations, and specific marketing campaigns to raise awareness [10].

Other researches analyzed the factors, level of knowledge, and motivation for blood donation among young people, including university students. The authors identified the most common phobias: fear of needles, fear of fainting when donating blood, lack of time, discomfort at the sight of blood, fear of infection during blood donation, lack of confidence in the equipment used. Fear of the needle reduces the probability of being a donor by $76 \%$; lack of time is also statistically significant. The authors found that blood donations were more likely spread among students who volunteered and took an active part in the political or religious movement. To combat fears, the authors recommend using altruistic feelings, primary care at an early age, ensuring the availability of time and proximity to blood donation centers by organizing mass blood collection events, for example, at the universities [11].

Fear of blood, injections, and fainting are obstacles to blood donation in Brazil. Efforts to recruit and retain blood donors should convey information about blood donation processes and eliminate misconceptions that may increase fear [17].

One of the marketing tools to combat fears is the possibilities of virtual reality, including $360^{\circ}$ video. Treatment centers are already using virtual reality possibilities to treat patients. Studies confirm the effectiveness of their use to combat phobias [7]. However, there are no studies on the effectiveness of virtual reality in dealing with phobias in healthy people.

Due to its clarity and convenience, virtual reality is a modern marketing tool for transferring information about complex processes. This tool has become increasingly popular in many sectors of the economy in recent years and is actively used by leading companies to improve interaction with consumers. However, from the point of view of the scientific approach, virtual reality in the service of blood is insufficiently studied.

According to many studies, young people are a useful category, because starting a career at a young age can be a donor for many years. However, young people are the least likely to return to donate blood compared to other age groups [19]. There are numerous publications on working with young people as potential donors [20], the focus is mainly on their motivation [21], the factors influencing their behavior, the reasons for refusing to donate, the intention to become donors $[3 ; 22]$. At the same time, there is almost no research on changing attitudes towards donation with modern marketing tools.

\section{THE AIM}

The study aims to identify the main fears of young people in the city of Sumy regarding blood donation and to develop ways to eliminate these phobias among students with modern marketing tools.
Moreover, the following scientific objectives have been identified:

1. determine the reasons for refusing a donation (objective and subjective);

2. identify the causes of blood donation that can be influenced;

3. propose measures to eliminate specific causes and myths.

\section{MATERIALS AND METHODS}

A survey among Sumy State University students on donation fears was conducted. The study was conducted for two months - from 1.12.2020 to 1.02.2021 among students of 1-6 courses. The general population is 13,500 people. The sample size is 374 people, $95 \%$ confidence interval, $5 \%$ confidence error. The sample is typically non-random. The research was conducted by questionnaire in paper and electronic form. The study involved 374 people aged 18 to 28 years (mean age 22 years).

The questionnaire contained the following questions:

1 . Did you donate blood as a donor?

2. If not, for what reason did you not do it?

3. Your age.

It created a $360^{\circ}$ video, which demonstrates donating blood process, showing further actions with the institution's collected blood. Video's duration is 20 minutes.

After that, a focus group among students who feared donation was organized. Ten participants were shown a $360^{\circ}$ video recorded in the center of the blood and discussed how to donate blood after watching the video.

\section{RESULTS AND DISCUSSION}

The analysis of the survey results revealed the main reasons that deter young people from being donors. Using the grouping method, the whole set of respondents was divided into main groups for deterrent reasons.

According to a survey (answers the question: If not, for what reason did you not do it) of 374 Sumy State University students, it was found that $61.7 \%$ of respondents (185 people) have a phobia of donating blood.

The main phobias are the fear of becoming infected during the procedure ( $37.7 \%$ or 113 people); fear of the procedure itself due to ignorance and misunderstanding what to wait for ( $14.0 \%$ or 42 people) and fear of the needle, blood, and the possibility of discomfort during the procedure ( $10.0 \%$ or 30 people).

Of the $115(38.3 \%)$ respondents who took part in the survey, other reasons not related to phobias were identified; in particular, $26.7 \%$ (80 people) answered that they could not be donors due to poor health, and 11, 6\% (35 people) due to personal laziness.

All these reasons can be divided into objective (which we cannot be influenced), and subjective (which can be corrected) (Table I).

Objective reasons, such as the inability to be a donor due to poor health, cannot be influenced directly.

Subjective reasons are adjustable. People afraid of being infected fear during the procedure, of procedure through 
Table I. Causes of blood donation, developed by the authors

\begin{tabular}{|c|c|c|}
\hline Reasons for not donating blood & $\begin{array}{l}\% \text { of } \\
\text { respondents }\end{array}$ & $\begin{array}{l}\text { Opportunity to influence the } \\
\text { change of attitude }\end{array}$ \\
\hline \multicolumn{3}{|l|}{ Objective reasons: } \\
\hline inability to be a donor due to poor health & 26,7 & no \\
\hline \multicolumn{3}{|l|}{ Subjective reasons: } \\
\hline fear of becoming infected during the procedure & 37,7 & yes \\
\hline $\begin{array}{l}\text { fear of the procedure itself due to ignorance and misunderstanding of what to } \\
\text { expect }\end{array}$ & 14,0 & yes \\
\hline fear of the needle, blood, and the possibility of discomfort during the procedure & 10,0 & yes \\
\hline personal laziness & 11,6 & yes / no \\
\hline
\end{tabular}

Table II. Advantages and disadvantages of 3600 video, systemized by the authors

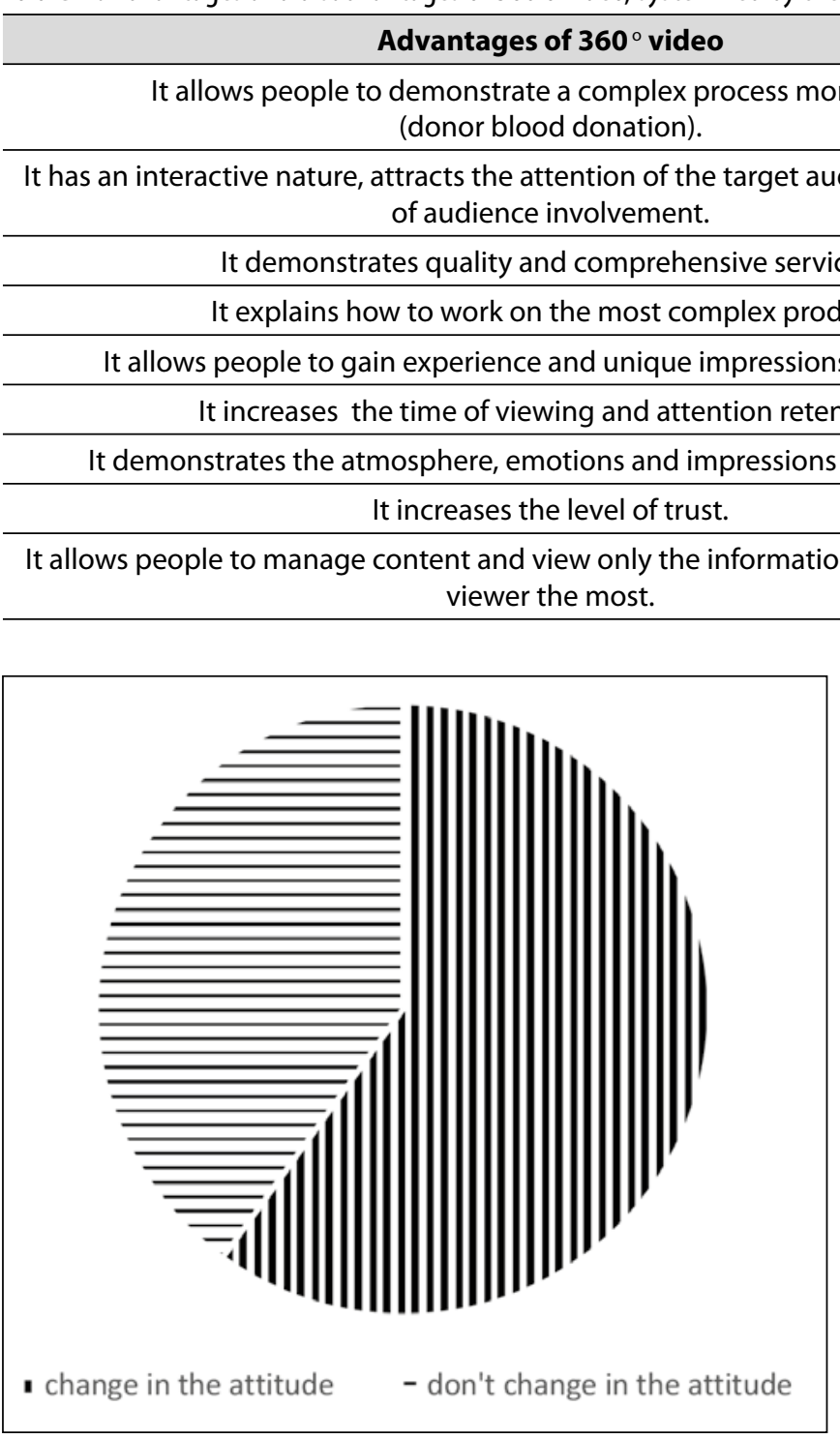

Fig. 1. The ratio of those who changed and did not change their attitude to donation

ignorance and misunderstanding of expecting, needle or blood, and the possibility of discomfort during the procedures. Laziness is a generalized cause that requires more detailed analysis.

Disadvantages of $360^{\circ}$ video

It is the time-consuming process of creating a video. It needs a powerful computer to create video. in advance. the viewer. 
Unfortunately, it was impossible to ask all respondents from research about the $360^{\circ}$ video. We interviewed only a small number of people in the first part of the research before and after watching this video. Moreover, it is impossible to say about the high effectiveness of this study. It needs further studying.

\section{CONCLUSIONS}

The study identified the main fears of donating blood as a donor, including fear of infection during the procedure, fear of the procedure itself, fear of the needle, blood, the possibility of discomfort, laziness, and inability to donate due to poor health.

Some of them are psychological and are associated with a lack of awareness about donating blood. Some of them can be influenced by marketing communication tools.

It was developed a $360^{\circ}$ video to the case number of donors. The video demonstrates donating blood, showing further actions with blood in a blood service facility. The video allows potential donors to fully immerse themselves in the virtual world, where they can see firsthand how the procedure takes place. As a result, some non-donor people will be able to ensure safety, sterility, to reduce the fear of donation and further increase the likelihood of becoming regular donors. This makes it possible to optimize quality management in the blood service.

Initially, it was expected an increase in those who changed attitudes towards blood donations. Only in a result of this study, it was found that it reaches $60 \%$ of the study group. This makes it possible to predict more accurately further the marketing activities results.

This study's results may be useful for blood service providers and organizations involved in donor advocacy, advertising campaigns to attract and retain donors.

\section{REFERENCES}

1. Liubchak V.V. Stan sluzhby krovi Ukrayiny [The condition of the blood service in Ukraine]. In: Liubchak V.V., Liubchak V.P., Tymchenko A.S. et al. Vyrobnycha transfuziolohiya [Industrial transfusiology]. Sumy:SumDU; 2017, p.253-263.(In Ukrainian).

2. Aldamiz-Echevarria C., Aguirre-Garcia M.S. A behavior model for blood donors and marketing strategies to retain and attract them. Revista Latino-Americana de Enfermagem. 2014;22(3):467-475.

3. Khomenko L., Saher L., Polcyn J. Analysis of the Marketing Activities in the Blood Service: Bibliometric Analysis. Health Economics and Management Review. 2020; 1(1):20-36.

4. Lyubchak V.V., Plaksa V.M., Pelo I.P. et al. Therapeutic Plasmapheresis in a Complex Treatment of Patients with Chronic Hepatitis. Wiadomosci Lekarskie. 2020;7(73):1454-1458.

5. Khomenko L.M, Saher L.Yu. \& Lyubchak V.V. Analiz reklamy sluzhby krovi v drukovanykh ZMI (na prykladi Sumskoho oblasnoho tsentru sluzhby krovi) [Analysis of blood supply service advertisements in print media (on the example of Sumy regional blood supply service center)]. Galician economic journal. 2020;66(5):170-179. (In Ukrainian).

6. Rosokhata A., Minchenko M., Khomenko L. et al. Renewable energy: a bibliometric analysis. E3S Web Conf. 2021;250:03002. doi: 10.1051/ e3sconf/202125003002.
7. Letunovska N.Ye, Internet marketing. In: Letunovska N.Ye, Khomenko L.M., Liulov 0.V. Marketynh u tsyfrovomu seredovyshchi [Marketing in the digital environment]. Sumy: SumDU; 2021, p. 130-162. (In Ukrainian).

8. Agrawal A. Social marketing of voluntary blood donation/organ donation. Global Journal of Transwfusion Medicine. 2016;1(1):69-71.

9. Bagot K. L., Murray A. L., Masser B. M. How can we improve retention of the first-time donor? A systematic review of the current evidence. Transfusion medicine reviews. 2016;30(2):81-91.

10. Klinkenberg E. F., In't Veld E.M.J.H., de Wit P.D. Blood donation barriers and facilitators of Sub-Saharan African migrants and minorities in Western high-income countries: a systematic review of the literature. Transfusion Medicine. 2019;29(1):28-41.

11. Henriques T., Quintal C. Young and healthy but reluctant to donate blood: An empirical study on attitudes and motivations of university students. Notas Económicas. 2018; 47(3): 1-16.

12. Soodejani M. T., Haghdoost A. A., Okhovati M. et al. Review Article Incidence of adverse reaction in blood donation: a systematic review. American Journal of Blood Research. 2020;5(10):145-150.

13. Gilchrist P.T., Masser B., Horsley K.J. et al. Predicting blood donation intention: the importance of fear. Transfusion. 2019; 59(12):3666-3673.

14. Kowalsky J. M., France C. R., France J. L. et al. Blood donation fears inventory: development and validation of a measure of fear specific to the blood donation setting. Transfusion And Apheresis Science. 2014;51(2):146-151.

15. France C. R., France J. L. Fear of blood draw is associated with inflated expectations of faint and prefaint reactions to blood donation. Transfusion. 2019;58(10):2360-2364.

16. Liubchak V.V. Svitovyy dosvid vykorystannya marketynhovykh instrumentiv dlya zaluchennya ta utrymannya bezoplatnykh dobrovil'nykh donoriv [World experience in using marketing tools to attract and retain free voluntary donors]. In: Liubchak V.V., Liubchak V.P., Tymchenko A.S. et al. Istoriya sluzhby krovi [History of blood service]. Sumy: SumDU; 2020, p. 303-316. (In Ukrainian).

17. Zucoloto M. L., Goncalez T., Menezes N. P. et al. Fear of blood, injections and fainting as barriers to blood donation in Brazil. Vox Sanguinis. 2019;114(1):38-46.

18. Muthivhi T. N., Olmsted M. G., Park H., Motivators and deterrents to blood donation among Black South Africans: a qualitative analysis of focus group data. Transfusion Medicine. 2015;25(4):249-258.

19. Priyono A., Masser B. M, Dyda A. et al. Longterm return and donation pattern of those who begin donating at different ages: A retrospective cohort analysis of blood donors in Australia. Transfusion. 2020;61(3):799-810.

20. Cicolini G., Comparcini D., Alfieri S. et al. Nursing students' knowledge and attitudes of blood donation: A multicentre study. Journal of Clinical Nursing. 2019;28(9-10):1829-1838.

21. Öhrner C., Kvist M., Wiberg K.B. et al. Why do young men lapse from blood donation? Vox Sanguinis. 2018;114(6):566-575.

22. Lemmens K.P.H., Abraham C., Hoekstra T. et al. Why don't young people volunteer to give blood? An investigation of the correlates of donation intentions among young nondonors. Transfusion. 2005;45(6):945-955 .

\section{ORCID and contributionship:}

Vladislav V. Liubchak: 0000-0003-0352-4355 A,B,D,F

Liliia M. Khomenko: 0000-0001-5690-1105 A,C,F

Michael P. Kovalishyn: 0000-0002-7120-0304 ${ }^{B, D}$

Viktoriia V. Ilyina: 0000-0002-3972-4327 ${ }^{B, E}$ 
Tetiana V. Babar - 0000-0002-5889-2429 ${ }^{B, E}$

Volodymyr V. Sikora - 0000-0003-4021-2334 B,E

Olha V. Simonova - 0000-0002-9542-9402 ${ }^{B, E}$

\section{Conflict of interest:}

The Authors declare no conflict of interest.

\section{CORRESPONDING AUTHOR}

Vladislav V. Liubchak

Medical Institute, Sumy State University

1 Sanatorna str, 40018, Sumy, Ukraine

tel: +380958000333

e-mal:ur3abm@i.ua

Received: 29.04 .2021

Accepted: 17.08 .2021

A - Work concept and design, B - Data collection and analysis, C - Responsibility for statistical analysis,

D-Writing the article, $\mathbf{E}-$ Critical review, $\mathbf{F}$ - Final approval of the article 